\title{
Systematic study of gene expression and transcription organization in the gntZ-ywaA region of the Bacillus subtilis genome
}

\author{
Ken-ichi Yoshida, Izumi Ishio, Eishi Nagakawa, Yoshiyuki Yamamoto, \\ Mami Yamamoto and Yasutaro Fujita
}

Author for correspondence: Y. Fujita. Tel: +8184936 2111. Fax: + 81849362459.

e-mail:yfujita@bt.fubt.fukuyama-u.ac.jp

Department of

Biotechnology, Faculty of Engineering, Fukuyama University, 985 Sanzo, Higashimura-cho, Fukuyama 729-0292, Japan

\begin{abstract}
Within the framework of the international project 'The functional analysis of the Bacillus subtilis genome' in Japan and Europe, the gene expression and transcription organization of the gntz-ywaA region (160 kb) of the $B$. subtilis genome has been systematically analysed. First, all unanalysed genes comprising more than 80 amino acids (125 genes) in this region were inactivated through integration of plasmid pMUTIN. No essential gene was found which could not be inactivated. All the integrants grew normally in both nutrient sporulation medium and glucose minimal medium. But an integrant in the yxbG gene exhibited an oligosporogenic phenotype in the nutrient sporulation medium. The synthesis of $\beta$-galactosidase was examined, as a reporter for expression of the inactivated genes, during growth and sporulation in the two media. The results indicated that $36 \%$ of the promoters were inactive when cells were grown in at least one of these two media. Furthermore, the transcription of the $\mathbf{1 1 9}$ genes in this region was analysed by Northern blotting, resulting in a transcription map. The results indicate that the gntZ-ywaA region contains at least 24 polycistronic operons, including several published ones. The operons newly found in this work are yxaAB, yхaGH, yхaJKL, yxbBA-yxnB-asnH-yxaM, yхbCD, yxcED, yxdJK, yxeFGH, yxeKLMNOPQ, yxeR-yxxB, hutPHUIGM, bgIPH-yxiE, wapA-yxxG, yxiM-deaD, katB-yxiS, yxjCDEF, yxjJ and yxkF-mmsX.
\end{abstract}

Keywords: Bacillus subtilis, genome, transcription, gene inactivation, gene expression

\section{INTRODUCTION}

Recently, tens of genomes of micro-organisms, including Saccharomyces cerevisiae (Goffeau et al., 1997) and Bacillus subtilis (Kunst et al., 1997), have been sequenced. Among the numerous identified genes, nearly half were found to be functionally unknown ones. Determining the functions of the unknown genes of these micro-organisms will be an important step for a more complete and comprehensive understanding of their cellular processes and metabolic pathways. Thus, international projects on functional genomics of genetically well characterized $S$. cerevisiae and B. subtilis have been started, in which many research groups are

Abbreviations: $\beta$-Gal, $\beta$-galactosidase; DSM, defined nutrient sporulation medium; MM, glucose minimal medium; SD, Shine-Dalgarno. participating. Very recently, great progress in the field of functional genomics of $S$. cerevisiae has been made by research groups in Europe and North America, with the production of deletion strains for more than 2000 unknown genes and the assaying of the phenotypes of 500 of them in parallel (Winzeler et al., 1999). On the other hand, many groups participating in the Japanese and European project on the functional analysis of the $B$. subtilis genome, which was initiated in 1996, have already inactivated nearly 2000 of the unanalysed genes through plasmid integration and are currently assaying the phenotypes of the integrants constructed, according to the following strategy.

The first step in the common strategy adopted in the $B$. subtilis genome function project is that each participating group is responsible for the inactivation of the unanalysed genes in a certain region of the genome. This 
inactivation is being carried out through integrational mutagenesis of a pMUTIN series of plasmids carrying lac $Z$ as a reporter gene, as illustrated in Fig. 1 (Vagner et al., 1998). Segments of the target genes are cloned into one of the pMUTIN plasmids, and the genomic copy is inactivated through a single- or double-crossover event. The promoter activities of the inactivated genes are monitored by measuring $\beta$-galactosidase $(\beta$-Gal) activity in cells during growth and sporulation, in both a defined nutrient sporulation medium (DSM) (Schaeffer et al., 1965) and a glucose minimal medium (MM). These two media were chosen for the $\beta$-Gal monitoring because the catabolic and anabolic pathways are predominantly utilized in the growth in the nutrient and minimal media, respectively. Furthermore, several groups are also carrying out Northern blotting analysis of the unanalysed genes in their assigned regions under the same growth conditions as those for the $\beta$-Gal monitoring, thereby constructing a transcription map of the region. These analyses are expected to provide valuable knowledge about the transcription organization, expression profiles and functions of the target genes. For the second step of the project, each of the laboratories has screened, or will screen, integrants constructed through easily conductable high-throughput protocols, mainly using plate tests.

We are responsible for the inactivation and expression analysis of the unanalysed genes in the gntZ-ywaA region $(160 \mathrm{~kb})$ of the $B$. subtilis genome, the sequence of which has been determined by us (Yoshida et al., 1996). As the first communication from the groups participating in this project, we describe the approach used for the inactivation of 125 unanalysed genes in this region, and the monitoring of their expression during cell growth and sporulation in DSM and MM. The results of our analyses provide valuable information about the essentiality of the inactivated genes, and their expression patterns during growth and sporulation in these media. We also describe the approach used for the construction of a transcription map of this region.

\section{METHODS}

Construction of bacterial strains. Table 1 comprises a list of the B. subtilis strains through integrational mutagenesis of one of the pMUTIN plasmids into the chromosome of B. subtilis Marburg 168 trpC2 (Anagnostopoulos \& Spizizen, 1961), the standard strain for the international project. The standard strain and pMUTIN plasmids [pMUTIN1, pMUTIN2 and pMUTIN4 (Vagner et al., 1998)] were obtained from Drs V. Vagner and S. D. Ehrlich (Institut National de la Recherche Agronomique, Jouy-en-Josas, France).

Inactivation of target genes by integrational mutagenesis through a single-crossover event, as illustrated in Fig. 1, was essentially carried out as described by Vagner et al. (1998). The details and minor modifications are provided on the web site for the Japanese B. subtilis genome function analysis project (http://bacillus.genome.ad.jp). Either the $5^{\prime}$ portion of the ORF of interest or the $5^{\prime}$ region covering the Shine-Dalgarno (SD) sequence and initiation codon (100$300 \mathrm{bp}$ long) was amplified by PCR using the chromosomal
DNA of strain $168 \operatorname{trpC} 2$ as a template. The sequences of the primer pairs, which were designed to generate flanking HindIII and BglII sites, are also available from the web site. The resulting PCR products were cleaved with HindIII and BglII, and then ligated into the HindIII/BamHI sites of pMUTIN2. The ligated DNAs were digested with BamHI and BglII to avoid self-ligation and used for the transformation of Escherichia coli strain C600 (Sambrook et al., 1989), ampicillin resistance was used as the marker. The resulting plasmids, after being checked for the correct structure, were used for the transformation (Fujita \& Fujita, 1983) of B. subtilis strain 168 $\operatorname{trp} C 2$ with erythromycin resistance as the marker. Correct integration of a single copy of the plasmid into the desired locus of the chromosome was confirmed by Southern blotting (Sambrook et al., 1989) or endonuclease-digestion analysis of the PCR product of the integrated region, results of which are provided on the web site.

Small target genes comprising less than approximately $200 \mathrm{bp}$ were inactivated through a double-crossover event, which resulted in the deletion of part of their coding regions. This deletional inactivation was carried out as follows. The $5^{\prime}$ portion of a target gene, including the SD sequence and translation-initiation codon, plus the $3^{\prime}$ portion containing the translation-termination codon were amplified separately by PCR using the chromosomal DNA as template. The sequences of the two primer sets, which were designed to generate flanking EcoRI and BglII, and HindIII and EcoRI sites, are available from the web site. Each PCR product was cleaved with either EcoRI and BglII or HindIII and EcoRI, and the resulting two fragments were ligated into the HindIII/BamHI sites of pMUTIN2. The ligated DNA was digested with $B a m \mathrm{HI}$ and $B g l \mathrm{II}$ to avoid self-ligation, and then used for the transformation of E. coli strain C600 as described above. The resulting plasmids were linearized through EcoRI digestion, and then used for the transformation of B. subtilis strain 168 trpC2 as described above.

Cell growth conditions and $\boldsymbol{\beta}$-Gal assay. B. subtilis cells with integrations in the desired target genes were grown on TBABG (tryptose blood agar containing $10 \mathrm{mM}$ glucose) plates containing $0.3 \mu \mathrm{g}$ erythromycin $\mathrm{ml}^{-1}$ at $30^{\circ} \mathrm{C}$ overnight. The cells were inoculated into $50 \mathrm{ml}$ DSM (Schaeffer et al., 1965) or $\mathrm{MM}$ in $200 \mathrm{ml}$ Erlenmeyer flasks at $\mathrm{OD}_{600} 0 \cdot 05$, and incubated at $37^{\circ} \mathrm{C}$ in a water bath shaker. The composition of the MM (pH 7.0) was as follows : $0 \cdot 4 \%$ glucose, $0 \cdot 2 \%$ glutamine, $50 \mu \mathrm{g}$ tryptophan $\mathrm{ml}^{-1}, 62 \mathrm{mM} \mathrm{K}_{2} \mathrm{HPO}_{4}, 44 \mathrm{mM} \mathrm{KH}_{2} \mathrm{PO}_{4}, 11.4 \mathrm{mM}$ $\mathrm{K}_{2} \mathrm{SO}_{4}, 3.4 \mathrm{mM}$ sodium citrate, $0.8 \mathrm{mM} \mathrm{MgSO}_{4}, 50 \mu \mathrm{M} \mathrm{CaCl}_{2}$, $24 \mu \mathrm{M} \mathrm{FeCl}_{3}, 13 \mu \mathrm{M} \mathrm{ZnCl}, 3 \mu \mathrm{M} \mathrm{Na}_{2} \mathrm{MoO}_{4}, 2 \cdot 5 \mu \mathrm{M} \mathrm{CuCl}_{2}$, $2 \cdot 5 \mu \mathrm{M} \mathrm{CoCl}_{2}$ and $1.32 \mu \mathrm{M} \mathrm{MnSO}{ }_{4}$.

During growth and sporulation in DSM or MM, $1 \mathrm{ml}$ aliquots $\left(\mathrm{OD}_{600} 0 \cdot 1-5 \cdot 0\right)$ were withdrawn at $30 \mathrm{~min}$ or $1 \mathrm{~h}$ intervals, and the cells were collected by centrifugation and stored at $-20^{\circ} \mathrm{C}$. The cells were suspended in $500 \mu \mathrm{l} \mathrm{Z}$ buffer $(60 \mathrm{mM}$ $\mathrm{Na}_{2} \mathrm{HPO}_{4}, 40 \mathrm{mM} \mathrm{NaH}_{2} \mathrm{PO}_{4}, 10 \mathrm{mM} \mathrm{KCl}, 1 \mathrm{mM} \mathrm{MgSO}_{4}$ and $1 \mathrm{mM}$ DTT) containing $10 \mu \mathrm{g}$ DNase $\mathrm{I} \mathrm{ml}^{-1}$ (Sigma) and $100 \mu \mathrm{g}$ lysozyme $\mathrm{ml}^{-1}$ (Sigma), and incubated at $37^{\circ} \mathrm{C}$ for $20 \mathrm{~min}$. After centrifugation $(27000 \mathrm{~g}, 20 \mathrm{~min})$, the supernatants were used for spectrophotometric $\beta$-Gal assays, as previously described by Atkinson et al. (1990). One unit of $\beta$ Gal activity was taken as the amount of the enzyme that produced $1 \mathrm{nmol} o$-nitrophenol $\mathrm{min}^{-1}$ at $25^{\circ} \mathrm{C}$.

Northern blotting. B. subtilis strain $168 \operatorname{trpC} 2$ cells grown in DSM or $\mathrm{MM}\left(\mathrm{OD}_{600} \times \mathrm{ml}=100-400\right)$ were harvested. RNA was then purified as described previously (Fujita et al., 1998). Northern blotting was also performed essentially as described 


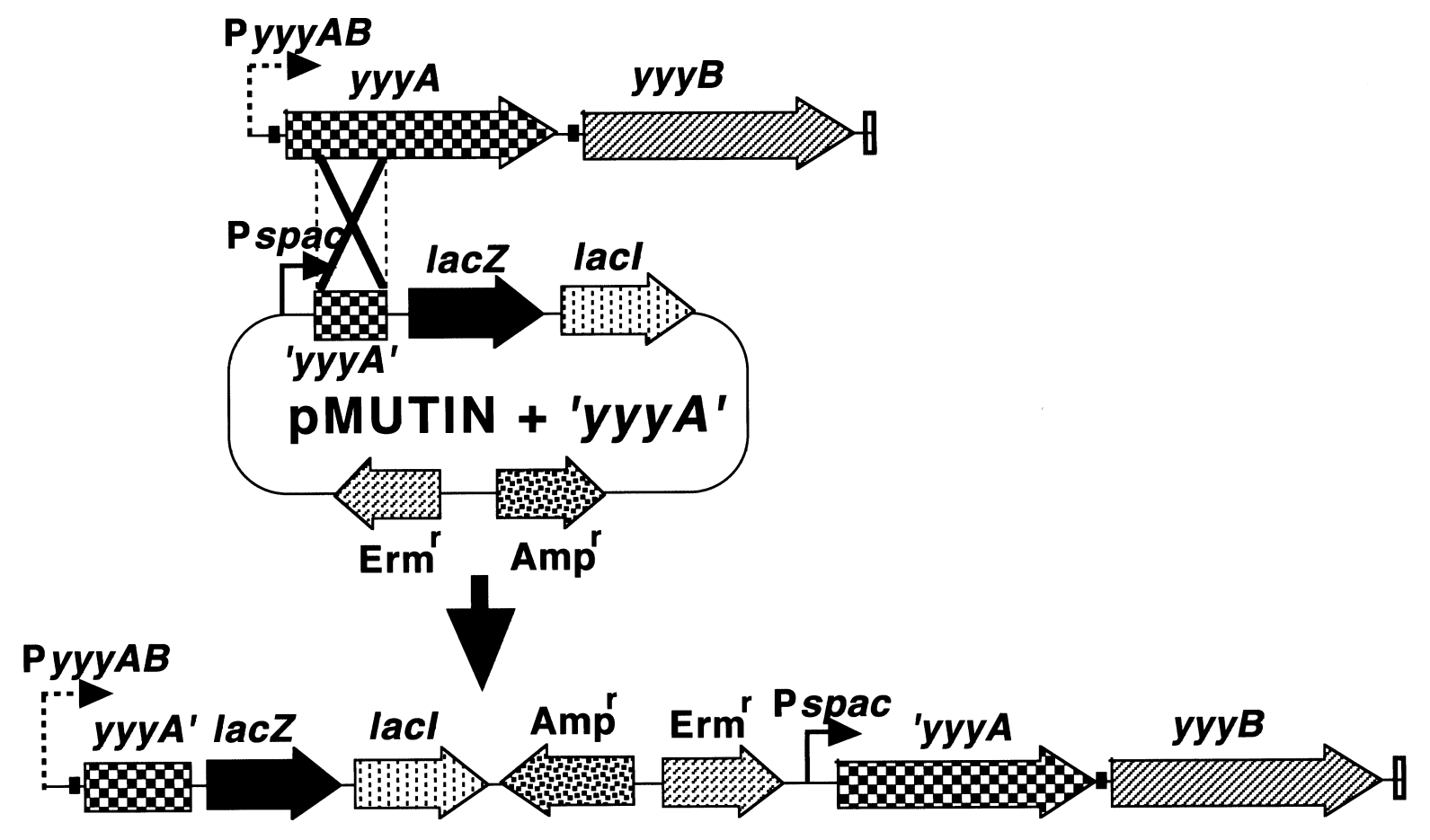

Fig. 1. Mutagenesis of a target gene through integration of pMUTIN. The disruption of a target gene ( $y y y A$ in this example) in an operon by integration of pMUTIN through a single-crossover event is illustrated. Details of the experimental procedures are given in Methods. A portion of the $5^{\prime}$ region of $y y y A$ ('yyyA') was cloned into pMUTIN1 or pMUTIN2 in $E$. coli strain $\mathrm{C} 600$ using ampicillin resistance as a selection marker. The resulting plasmid was used for transformation of $B$. subtilis strain $168 \operatorname{trpC2}$ using erythromycin resistance as a selection marker. The construction of the resulting integrant is shown. $y y y A$ expression under the control of the Pyy $A B$ promoter can be monitored as lac $Z$ expression. The downstream gene $(y y y B)$ under the control of the Pspac promoter can be expressed through the addition of IPTG to the medium to avoid the eventual polar effect of the mutation in the upstream gene. As described by Vagner et al. (1998), the target gene (yyyA) can be inactivated through the replacement of its promoter with the Pspac promoter. When a target gene was essential for cell growth or it was hard to disrupt with the above method, a short DNA stretch carrying the SD and initiation codon of the gene was cloned into pMUTIN4 containing the Pspac promoter. The resulting plasmid was used for transformation, with erythromycin resistance as the selection marker, in the presence of IPTG on the plates.

previously (Sambrook et al., 1989; Yoshida et al., 1997), using total RNA and the ${ }^{32} \mathrm{P}$-labelled PCR product for the $5^{\prime}$ portion of the ORF of the analysed gene as a double-strandspecific DNA probe; the primer sequences are provided on the web site.

\section{RESULTS AND DISCUSSION}

\section{Inactivation of the unanalysed genes in the gntZ-ywaA genomic region}

Of the 155 genes in the $160 \mathrm{~kb}$ gntZ-ywaA region of the B. subtilis genome (Yoshida et al., 1996; Kunst et al., 1997), we did not inactivate gntPKR, htpG, iolSR, deoR, dra, пирC, pdp, hutGIUHP, bglP, bglH, wapA, licT, bglS and licRBCAH because they had already been characterized and $y x z G$ had no clear SD sequence. The $y x e J, y x i L, y x z E, y x z F$ and $y x l C D E$ genes were too small to be inactivated by pMUTIN integration through a single-crossover event. Nevertheless, the inactivation of $y x l C D E$ was achieved through double-crossover recombination. The resulting 125 integrants are listed in Table 1, and the inactivated genes are also indicated in
Fig. 2. The gene-inactivation studies indicated that there were no essential genes for growth under the conditions examined among the 125 inactivated genes.

\section{Examination of $\beta$-Gal synthesis under the control of the promoters of the inactivated genes}

Expression of the inactivated genes was investigated by monitoring the activity of $\beta$-Gal, which was used as the reporter, during growth and sporulation. Sporulation of the 125 integrants after $24 \mathrm{~h}$ incubation in DSM was also examined microscopically, which revealed that only one integrant, YXBGd, was oligosporogenic. The efficiency of spore formation (heat-resistant) of this integrant after $24 \mathrm{~h}$ incubation in DSM was $3 \%$ that of the viable cells, while that of strain $168 \operatorname{trpC} 2$ was over $70 \%$.

Table 1 shows the expression levels of the 125 inactivated genes during growth and sporulation in DSM and MM. This table also shows the maximal $\beta$-Gal activities of the integrant cultures during growth and sporulation in liquid DSM and MM, together with their expression patterns. More detailed results of the moni- 
Table 1. Expression levels of the 125 inactivated genes in the gntZ-ywaA region

The experiments were repeated at least twice until consistent results were obtained. Representative results are shown.

\begin{tabular}{|c|c|c|c|c|c|}
\hline \multirow[t]{2}{*}{ Mutant* } & \multicolumn{2}{|c|}{$\begin{array}{c}\text { Maximal } \beta \text {-Gal activity }\left[\mathrm{U} \mathrm{mg}^{-1} \text { (time, }\right. \\
\text { expression pattern) }]\end{array}$} & \multirow[t]{2}{*}{ Mutant* } & \multicolumn{2}{|c|}{$\begin{array}{c}\text { Maximal } \beta \text {-Gal activity }\left[\mathrm{U} \mathrm{mg}^{-1} \text { (time, }\right. \\
\text { expression pattern)] }\end{array}$} \\
\hline & DSM & MM & & DSM & MM \\
\hline GNTZd & $41(2, C)$ & $45(6, C)$ & YXIDd & $9(4 \cdot 5, \mathrm{C}+\mathrm{LV})$ & $47(9, C+S)$ \\
\hline YXAAd & $6(1, C)$ & $23(8, \mathrm{LV})$ & YXXDp & $57(2, \mathrm{C})$ & $157(9, \mathrm{LV})$ \\
\hline YXABd & $\mathrm{N}$ & $6(10, \mathrm{LV})$ & YXXEd & $27(0 \cdot 5, \mathrm{C})$ & $73(8, S)$ \\
\hline YXACd & $\mathrm{N}$ & $4(7 \cdot 5, \mathrm{LV})$ & YXIEd & $106(0 \cdot 5, \mathrm{C}+\mathrm{LV})$ & $487(9, \mathrm{C}+\mathrm{S})$ \\
\hline YXADd & $81(2 \cdot 5, \mathrm{C})$ & $39(9, \mathrm{C})$ & YXXFd & $\mathrm{N}$ & $27(9, \mathrm{C}+\mathrm{LV})$ \\
\hline YXNAd & $\mathrm{N}$ & $\mathrm{N}$ & YXXGp & $164(4, C+L V)$ & $443(9, \mathrm{LV})$ \\
\hline YXAFd & $14(2, \mathrm{LV})$ & $6(7, C+L V)$ & YXIFd & $10(4 \cdot 5, \mathrm{LV})$ & $42(9, \mathrm{LV})$ \\
\hline YXAGd & $\mathrm{N}$ & $\mathrm{N}$ & YXZCd & $9(4 \cdot 5, \mathrm{LV})$ & $42(9, \mathrm{LV})$ \\
\hline YXAHd & $\mathrm{N}$ & $\mathrm{N}$ & YXIGd & $9(4 \cdot 5, \mathrm{LV})$ & $29(9, \mathrm{LV})$ \\
\hline YXAId & $201(0 \cdot 5, \mathrm{C})$ & $222(7, \mathrm{LV})$ & YXIHd & $7(4 \cdot 5, \mathrm{LV})$ & $30(9, \mathrm{LV})$ \\
\hline YXAJd & $19(0 \cdot 5, \mathrm{C})$ & $43(8, \mathrm{LV})$ & YXIId & $\mathrm{N}$ & $6(9, S)$ \\
\hline YXAKd & $31(0 \cdot 5, \mathrm{C})$ & $69(9, \mathrm{LV})$ & YXIJd & $5(4 \cdot 5, \mathrm{C})$ & $20(9, S)$ \\
\hline YXALd & $67(0 \cdot 5, \mathrm{C})$ & $178(9, \mathrm{LV})$ & YXIKd & $5(4 \cdot 5, \mathrm{C})$ & $15(9, \mathrm{LV})$ \\
\hline YXAMd & $29(4, \mathrm{~T} 0)$ & $42(9, C+S)$ & YXIMd & $15(7 \cdot 5, \mathrm{~T} 2)$ & $3(9, S)$ \\
\hline ASNHd & $475(5 \cdot 5, \mathrm{~T} 0)$ & $435(3, \mathrm{C}+\mathrm{S})$ & DEADd & $5(0 \cdot 5, C)$ & $8(8, S)$ \\
\hline YXNBd & $1424(9$, T0) & $468(9, \mathrm{C}+\mathrm{S})$ & YXIOd & $\mathrm{N}$ & $5(7, \mathrm{C}+\mathrm{LV})$ \\
\hline YXBAd & $1499(9, \mathrm{~T} 0)$ & $677(9, \mathrm{C}+\mathrm{S})$ & YXIPd & $5(0 \cdot 5, \mathrm{C})$ & $53(8, \mathrm{LV})$ \\
\hline YXBBd & $2710(4 \cdot 5, \mathrm{~T} 0)$ & $1891(8, \mathrm{C}+\mathrm{S})$ & YXIQd & $29(7, \mathrm{~T} 2)$ & $\mathrm{N}$ \\
\hline YXBCd & $111(5, \mathrm{~T} 0)$ & $116(9, C+S)$ & KATBd & $\mathrm{N}$ & $\mathrm{N}$ \\
\hline YXBDd & $12(4 \cdot 5, \mathrm{~T} 0)$ & $44(9, C+S)$ & YXISd & $30(0 \cdot 5, \mathrm{C})$ & $20(9, \mathrm{LV}+\mathrm{S})$ \\
\hline ALDXd & $\mathrm{N}$ & $\mathrm{N}$ & YXITd & $8(9, C)$ & $6(9, S)$ \\
\hline YXBFd & $\mathrm{N}$ & $3(8 \cdot 5, \mathrm{LV})$ & YXJAd & $16(3, \mathrm{C})$ & $20(9, \mathrm{C}+\mathrm{LV})$ \\
\hline YXBGd & $\mathrm{N}$ & $7(3, C)$ & YXJBd & $10(2, \mathrm{LV})$ & $17(9, \mathrm{LV})$ \\
\hline YXCAd & $6(0 \cdot 5, \mathrm{C})$ & $16(3, \mathrm{C})$ & YXJCd & $32(6, \mathrm{~T} 1)$ & $\mathrm{N}$ \\
\hline YXCCd & $28(0 \cdot 5, \mathrm{C})$ & $6(4, C)$ & YXJDd & $43(6 \cdot 5, \mathrm{~T} 1)$ & $\mathrm{N}$ \\
\hline YXCDd & $7(5, C)$ & $9(9, \mathrm{C}+\mathrm{LV})$ & YXJEd & $20(7 \cdot 5, \mathrm{~T} 1)$ & $\mathrm{N}$ \\
\hline YXCEd & $6(3 \cdot 5, C)$ & $12(8, \mathrm{C}+\mathrm{LV})$ & YXJFd & $17(5 \cdot 5, \mathrm{~T} 1)$ & $\mathrm{N}$ \\
\hline IOLAd & $47(5 \cdot 5, \mathrm{LV})$ & $13(8, \mathrm{LV})$ & YXJGd & $5(2, C)$ & $109(5, \mathrm{C}+\mathrm{LV})$ \\
\hline IOLBd & $25(4 \cdot 5, \mathrm{LV})$ & $10(9, \mathrm{C})$ & YXJHd & $6(0 \cdot 5, C)$ & $71(5, \mathrm{C}+\mathrm{LV})$ \\
\hline IOLCd & $9(5 \cdot 5, \mathrm{LV})$ & $5(3, C)$ & YXJId & $9(4, \mathrm{LV})$ & $12(8, S)$ \\
\hline IOLDd & $13(5 \cdot 5, \mathrm{LV})$ & $3(9, C)$ & YXJJd & $98(4, \mathrm{LV})$ & $82(4, C)$ \\
\hline IOLEd & $29(5 \cdot 5, \mathrm{LV})$ & $5(9, S)$ & PEPTd & $96(1, C)$ & $127(9, \mathrm{C}+\mathrm{LV})$ \\
\hline IOLFd & $715(7, \mathrm{~T} 1)$ & $21(3, \mathrm{C})$ & YXJLd & $\mathrm{N}$ & $\mathrm{N}$ \\
\hline IOLGd & $721(5, \mathrm{~T} 0)$ & $8(3, C)$ & YXJMp & $\mathrm{N}$ & $\mathrm{N}$ \\
\hline IOLHd & $2391(3, \mathrm{LV})$ & $58(3, \mathrm{C})$ & YXJNd & $6(3, C)$ & $6(7, C)$ \\
\hline IOLId & 1339 (3, LV) & $136(3, \mathrm{C})$ & YXJOd & $\mathrm{N}$ & $6(3, C)$ \\
\hline IOLJd & $1096(3, \mathrm{LV})$ & $97(3, \mathrm{C})$ & YXKAd & $\mathrm{N}$ & $\mathrm{N}$ \\
\hline YXDJd & $11(3 \cdot 5, \mathrm{C}+\mathrm{LV})$ & $6(9, \mathrm{C}+\mathrm{LV})$ & GALEd & $38(3, \mathrm{C})$ & $27(9, \mathrm{C}+\mathrm{LV})$ \\
\hline YXDKd & $5(1 \cdot 5, C)$ & $\mathrm{N}$ & YXKCd & $177(4, \mathrm{LV})$ & $389(5, \mathrm{C}+\mathrm{LV})$ \\
\hline YXDLd & $6(5, \mathrm{LV})$ & $3(8, C)$ & YXKDd & $8(1 \cdot 5, C)$ & $3(7, \mathrm{LV})$ \\
\hline YXDMd & $\mathrm{N}$ & $3(4, C)$ & ALDYd & $\mathrm{N}$ & $\mathrm{N}$ \\
\hline YXEAd & $\mathrm{N}$ & $\mathrm{N}$ & YXKFd & $9(8 \cdot 5, \mathrm{C}+\mathrm{LV})$ & $7(9, \mathrm{LV})$ \\
\hline YXEBd & $30(3 \cdot 5, \mathrm{C}+\mathrm{LV})$ & $60(8, C+S)$ & MSMXd & $2550(6, \mathrm{C}+\mathrm{LV})$ & $564(3, \mathrm{C}+\mathrm{LV})$ \\
\hline YXECd & $59(2 \cdot 5, \mathrm{LV})$ & $65(7, \mathrm{C})$ & YXKHd & $8(3 \cdot 5, \mathrm{LV})$ & $19(5, \mathrm{C}+\mathrm{LV})$ \\
\hline YXEDd & $9(9 \cdot 5, \mathrm{~T} 3)$ & $\mathrm{N}$ & YXKId & $6(0 \cdot 5, \mathrm{C})$ & $7(5, \mathrm{LV})$ \\
\hline YXEEd & $145(9 \cdot 5, \mathrm{~T} 4)$ & $7(7, C)$ & YXKJd & $\mathrm{N}$ & $3(9, \mathrm{LV})$ \\
\hline YXEFd & $\mathrm{N}$ & $3(9, \mathrm{LV})$ & CYDAd & $6(0 \cdot 5, C)$ & $5(9, C+S)$ \\
\hline YXEGd & $\mathrm{N}$ & $5(9, \mathrm{LV})$ & CYDBd & $7(0 \cdot 5, C)$ & $9(9, C+S)$ \\
\hline YXEHd & $6(2, \mathrm{LV})$ & $14(7, \mathrm{C}+\mathrm{LV})$ & CYDCd & $\mathrm{N}$ & $4(9, C+S)$ \\
\hline YXEId & $\mathrm{N}$ & $5(7, C+S)$ & CYDDd & $\mathrm{N}$ & $3(9, C+S)$ \\
\hline YXEKd & $13(2 \cdot 5, \mathrm{LV})$ & $26(7, \mathrm{C}+\mathrm{LV})$ & YXKOd & $\mathrm{N}$ & $8(3, C)$ \\
\hline YXELd & $\mathrm{N}$ & $6(7, \mathrm{LV})$ & YXLAd & $\mathrm{N}$ & $3(3, C)$ \\
\hline YXEMp & $7(2 \cdot 5, \mathrm{LV})$ & $9(7, \mathrm{C}+\mathrm{LV})$ & SIGYd & $\mathrm{N}$ & $\mathrm{N}$ \\
\hline YXENd & $9(3, \mathrm{LV})$ & $13(7, \mathrm{C}+\mathrm{LV})$ & YXLCdd & $9(9 \cdot 5, \mathrm{C}+\mathrm{T} 3)$ & $7(9, \mathrm{C}+\mathrm{LV})$ \\
\hline YXEOd & $12(1 \cdot 5, \mathrm{LV})$ & $8(7, C+L V)$ & YXLDdd & $\mathrm{N}$ & $\mathrm{N}$ \\
\hline YXEPd & $5(2 \cdot 5, \mathrm{LV})$ & $11(8, \mathrm{C}+\mathrm{LV})$ & YXLEdd & $\mathrm{N}$ & $\mathrm{N}$ \\
\hline YXEQd & $8(3 \cdot 5, \mathrm{LV})$ & $19(8, \mathrm{C}+\mathrm{LV})$ & YXLFd & $10(9 \cdot 5, \mathrm{LV}+\mathrm{T} 3)$ & $5(8, C)$ \\
\hline YXERd & $\mathrm{N}$ & $8(8, C)$ & YXLGd & $\mathrm{N}$ & $\mathrm{N}$ \\
\hline YXXBd & $\mathrm{N}$ & $\mathrm{N}$ & YXLHd & $\mathrm{N}$ & $\mathrm{N}$ \\
\hline HUTMd & $166(6, \mathrm{~T} 0)$ & $3(4, C)$ & KATXd & $\mathrm{N}$ & $3(4, C)$ \\
\hline YXIAd & $\mathrm{N}$ & $\mathrm{N}$ & YXLJd & $\mathrm{N}$ & $\mathrm{N}$ \\
\hline YXIBd & $20(6, \mathrm{C}+\mathrm{T} 0)$ & $78(9, S)$ & YWAAd & $22(4, \mathrm{C}+\mathrm{T} 0)$ & $101(9, \mathrm{LV})$ \\
\hline YXICd & $55(0 \cdot 5, \mathrm{C})$ & $128(9, S)$ & & & \\
\hline
\end{tabular}

Table 1. For footnote see facing page. 
toring of $\beta$-Gal synthesis can be found on the web site (http://bacillus.genome.ad.jp).

Among the 125 genes whose expression was examined by monitoring of $\beta$-Gal synthesis, 80 genes were expressed in both DSM and MM, 7 in DSM only, 20 in MM only and 18 in neither medium (Table 1). Seventeen genes (yxaI, asnH, yxnB, yxbABC, iolFGHIJ, yxeE, hutM, $y x i E, y x x G, y x k C$ and $m s m X)$ were strongly expressed in cells during growth and sporulation in DSM: the cells produced more than $100 \mathrm{U} \beta$-Gal (mg protein $)^{-1}$. Of these genes, iolFGHJ, yxeE and hutM were not expressed strongly in cells grown in MM. $y x a L, y x i C, y x x D, y x j G$, pepT $T$ and $y w a A$ were expressed strongly in MM only. Table 1 also shows the expression patterns of the genes during growth and sporulation.

The expression profiles of the inactivated genes might not fully reflect their expression in vivo, because expression of the genes examined might be autoregulated or an inducer of an operon comprising several genes might be synthesized through the enzyme reaction(s) catalysed by their gene product(s). Moreover, it was observed that different locations of integration during mutagenesis affected the expression of lacZ (Y. Fujita \& N. Yanai, unpublished results). It appears that the stability of an artificial mRNA encoding $\beta$-Gal, whose synthesis starts from the promoter of the target gene, is sometimes affected by the location of the crossover.

\section{Construction of a transcription map of the gntZ-ywaA region}

We performed Northern analysis of 119 genes to construct a transcription map of the gntZ-ywaA region (Fig. 2). Total RNA was extracted from cells of strain $168 \operatorname{trpC} 2$ grown in either DSM or MM and used for Northern blotting. The hybridization results are provided on the web site (http://bacillus.genome.ad.jp).

Fig. 2 shows the transcripts that were detected on Northern blots for the genes between gnt $Z$ and $y w a A$, together with their sizes, the times at which the cells were harvested and the medium used. The transcripts are placed beneath the analysed genes on the assumption that they were synthesized from upstream of them. When the same size of transcript was detected with multiple DNA probes from successive genes, the transcripts are appropriately placed beneath them according to their size (Fig. 2). Of the 119 genes analysed, the transcripts of 77 genes were detected in both DSM and MM, 19 were detected in DSM only and 4 were detected in MM only. The transcripts of 19 genes were not detected in either medium.

A comparison of Table 1 and Fig. 2 indicates that the results of Northern blotting did not often coincide with those of $\beta$-Gal measurement. Among 115 genes, the expression of which was analysed by both Northern blotting and $\beta$-Gal measurement, the expression of 11 was detected only on Northern blotting and that of 14 was detected only on $\beta$-Gal measurement. Moreover, more than $10 \mathrm{U} \beta$-Gal $(\mathrm{mg} \text { protein })^{-1}$ was synthesized by the integrants in nearly $30 \%$ of the instances where no transcript of the target genes was detected in DSM or MM. One explanation for this is that there are differences in stability between the mRNAs of different target genes. Sometimes, rRNAs $(2.9$ and $1.5 \mathrm{~kb})$ can hamper the detection of specific mRNA. For five genes ( $y x e A, y x j L, y x j M, y x k A$ and ald Y), we could not detect transcription by either $\beta$-gal measurement or Northern blotting (Table 1 and Fig. 2).

Northern experiments revealed the operon structure of this region. The 14 newly found polycistronic operons were as follows: $y x a A B, y x a G H, y x a J K L, y x b B A-$ $y x n B-a s n H-y x a M, y x b C D, y x c E D, y x d J K, y x e F G H$, $y x e K L M N O P Q, y x e R-y x x B, y x i M-d e a D, y x j C D E F$, $y x i J I$ and $y x k F-m s m X$. Recently, we detected $c y d A B C D$ operon expression in cells grown on either solid DSM and MM or in liquid NSMP medium (Fujita \& Freese, 1981) supplemented with glucose, but not in liquid DSM containing glucose or in liquid MM (Fig. 2) (Winstedt et al., 1998). As shown in Fig. 2, we also detected the following polycistronic transcripts: $11.5 \mathrm{~kb}$ for iolABCDEFGHIJ, $4.5 \mathrm{~kb}$ for deoR-dra-nupC-pdp, $8.0 \mathrm{~kb}$ for hutPHUIGM, $4.0 \mathrm{~kb}$ for bglPH-yxiE, $8.0 \mathrm{~kb}$ for wapA$y x x G$, and $2.5 \mathrm{~kb}$ for katB-yxiS. In addition, we found a $4.3 \mathrm{~kb}$ transcript covering $\operatorname{sig} Y-y x l C D E F G$. We can not explain at the moment why this transcript continued to be synthesized to the oppositely oriented $y x l H$ gene without termination of its synthesis between $y x l G$ and $y x l H$. Table 1 also shows that there are very similar expression patterns for the integrants of the genes corresponding to polycistronic operons, except for $y x a G-y x a H, y x e R-y x x B$ and katB-yxiS (Table 1).

In conclusion, we emphasize that this systematic study of gene expression and organization has provided valuable information for comparison with the results of future microarray-based analysis.

\footnotetext{
*In the nomenclature for the mutants the four capital letters of the gene names were used; the lower-case letters $\mathrm{d}$, $\mathrm{p}$ and dd indicate integrational disruption through a single-crossover event, promoter replacement through a single crossover and deletional replacement through a double crossover, respectively. Integrants, the target genes of which are cotranscribed with other genes, are shown in bold. The operon structures of these genes are shown in Fig. 2.

$\dagger \beta$-Gal synthesis during growth and sporulation of the integrants in DSM and MM was monitored as described in the text. The actual data are obtainable from the web site (http://bacillus.genome.ad.jp). The maximal $\beta$-Gal activities of integrants during growth and sporulation are shown as $\mathrm{U}(\mathrm{mg} \text { protein })^{-1}$, together with the corresponding incubation times $(\mathrm{h})$ after inoculation and the lac $Z$ expression patterns. The expression patterns of $l a c Z$ are classified as no synthesis $(\mathrm{N})$, constitutive synthesis $(\mathrm{C})$ and induction at the late vegetative (LV), sporulation (T0 to T4), or stationary (S) phases. The cells entered the sporulation phase in DSM $3.5 \mathrm{~h}$ after inoculation (T0), while cells entered the stationary phase in MM $7 \mathrm{~h}$ after inoculation.
} 

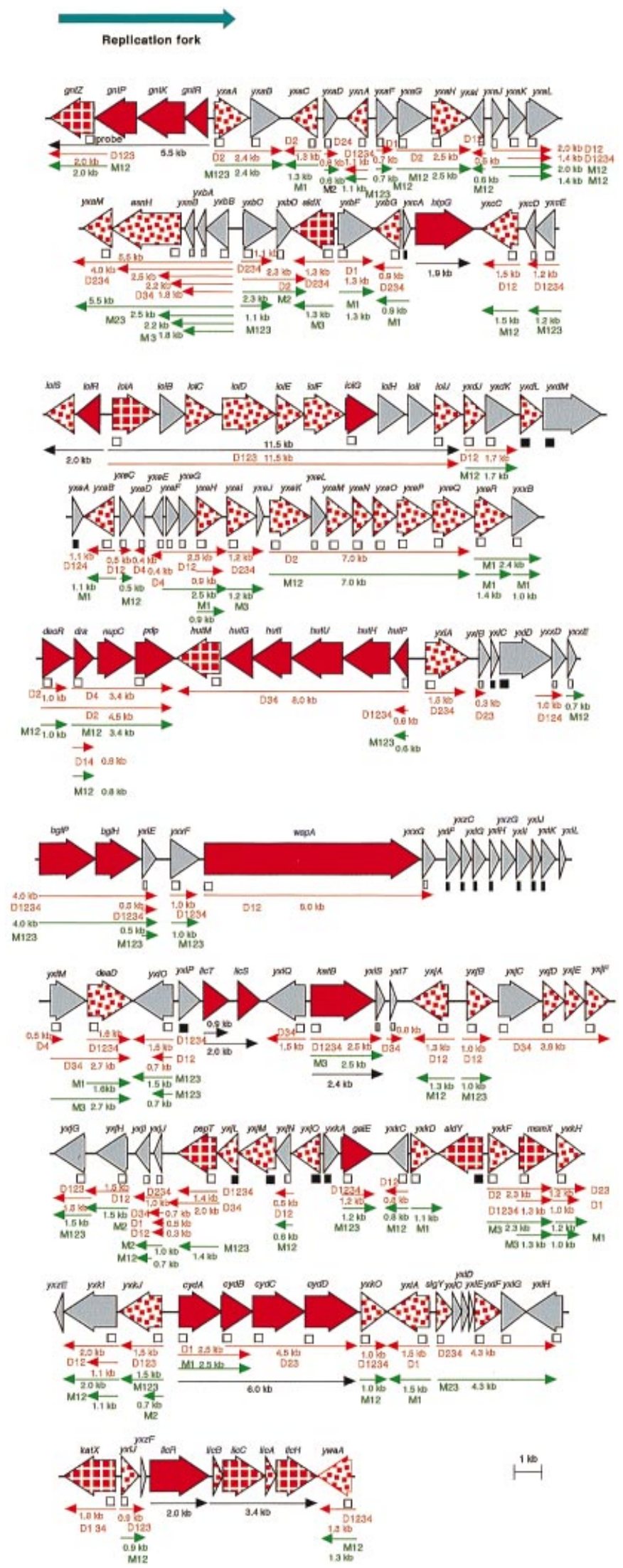

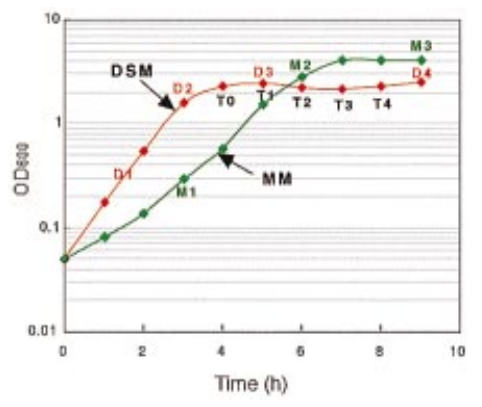

Fig. 2. Genes and transcription mapping of the gntZ-ywaA genomic region. The gntZ-ywaA region contains 155 genes, as shown in the figure (Kunst et al., 1997). Red arrows indicate genes whose functions are known, meshed red arrows indicate genes whose most probable functions are known from the results of similarity searches of their products, red-dotted arrows indicate genes whose products show meaningful similarity to other proteins and grey arrows indicate genes exhibiting no clear similarity; the data obtained on these similarity searches are available from the web site (http://bacillus.genome.ad.jp). The names of the 125 genes inactivated on pMUTIN integration are indicated in black text, while the 30 genes not inactivated are indicated in blue text. Squares underneath the genes indicate the locations of the PCR products used for Northern blotting: white and black squares indicate the probes with which positive and negative results were obtained, respectively. The red and green arrows indicate the transcripts obtained with DSM and $\mathrm{MM}$, respectively. The black arrows indicate transcripts whose appearance has already been reported, these are: gntRKPZ (Fujita et al., 1986), htpG (Schulz et al., 1997), iolRS and iolABCDEFGHIJ Yoshida et al., 1997), licTS (Schnetz et al., 1996), cydABCD (Winstedt et al., 1998), lick and licBCAH (Tobisch et al., 1997) and katB (= katE) (Engelmann et al., 1995). At the top right of the figure, the graph shows the times at which the cells were harvested and the growth media for total RNA preparation. 


\section{ACKNOWLEDGEMENTS}

We thank H. Ohhashi, K. Ohnishi, D. Nakayama, Y. Shimasaki, N. Aomori, S. Mukai, S. Ohyama, K. Ogura, H. Yokota, T. Adachi, H. Hara, Y. Ihori, H. Kataoka, Y. Kawabe, K. Kawano, Y. Omote, D. Maki, M. Matsunaga and K. Yokotani for their help in the experiments. We are also grateful to $\mathrm{C}$. Kang for critical reading of the manuscript. This work was supported by a grant, JSPS-RFTF96L00105, from the Japan Society for the Promotion of Science.

\section{REFERENCES}

Anagnostopoulos, C. \& Spizizen, J. (1961). Requirements for transformation in Bacillus subtilis. J Bacteriol 81, 741-746.

Atkinson, M. R., Wray, L. V., Jr \& Fisher, S. H. (1990). Regulation of histidine and proline degradation enzymes by amino acid availability in Bacillus subtilis. J Bacteriol 172, 4758-4765.

Engelmann, S., Lindner, C. \& Hecker, M. (1995). Cloning, nucleotide sequence, and regulation of katE encoding a $\sigma^{\mathrm{B}}$ dependent catalase in Bacillus subtilis. J Bacteriol 177, 5598-5605.

Fujita, Y. \& Freese, E. (1981). Isolation and properties of a Bacillus subtilis mutant unable to produce fructose bisphosphatase. $J$ Bacteriol 145, 760-767.

Fujita, Y. \& Fujita, T. (1983). Genetic analysis of a pleiotropic deletion mutation $(\Delta i g f)$ in Bacillus subtilis. J Bacteriol 154, 864-869.

Fujita, Y., Fujita, T., Miwa, Y., Nihashi, J. \& Aratani, Y. (1986). Organization and transcription of the gluconate operon, gnt, of Bacillus subtilis. J Biol Chem 261, 13744-13753.

Fujita, Y., Yoshida, K., Miwa, Y., Yanai, N., Nagakawa, E. \& Kasahara, Y. (1998). Identification and expression of the Bacillus subtilis fructose-1,6-bisphosphatase gene $(f b p)$. J Bacteriol 180, 4309-4313.

Goffeau, A., Aert, R., Agostini-Carbone, M. L. \& $\mathbf{6 3 0}$ other authors (1997). The yeast genome directory. Nature, 387 (suppl.), 5-105.

Kunst, F., Ogasawara, N., Moszer, I. \& 148 other authors (1997). The complete genome sequence of the Gram-positive bacterium Bacillus subtilis. Nature, 390, 249-256.
Sambrook, J., Fritsch, E. F. \& Maniatis, T. (1989). Molecular Cloning: a Laboratory Manual, 2nd edn. Cold Spring Harbor, NY: Cold Spring Harbor Laboratory.

Schaeffer, P., Millet, J. \& Aubert, J. P. (1965). Catabolite repression of bacterial sporulation. Proc Natl Acad Sci USA 54, 704-711.

Schnetz, K., Stülke, J., Gerty, S., Krüger, S., Krieg, M., Hecker, M. \& Rak, B. (1996). LicT, a Bacillus subtilis transcriptional antiterminator protein of the BglG family. J Bacteriol 178, 1971-1979.

Schulz, A., Schwab, S., Homuth, G., Versteeg, S. \& Schumann, W. (1997). The $h t p G$ gene of Bacillus subtilis belongs to class III heat shock genes and is under negative control. J Bacteriol 179, 3103-3109.

Tobisch, S., Glaser, P., Krüger, S. \& Hecker, M. (1997). Identification and characterization of a new $\beta$-glucoside utilization system in Bacillus subtilis. J Bacteriol 179, 496-506.

Vagner, V., Dervyn, E. \& Ehrlich, S. D. (1998). A vector for systematic gene inactivation in Bacillus subtilis. Microbiology 144, 3097-3104.

Winstedt, L., Yoshida, K., Fujita, Y. \& von Wachenfeldt, C. (1998). Cytochrome $b d$ biosynthesis in Bacillus subtilis: characterization of the cydABCD operon. J Bacteriol 180, 6571-6580.

Winzeler, E. A., Shoemaker, D. D., Astromoff, A. \& 49 other authors (1999). Functional characterization of the $S$. cerevisiae genome by gene deletion and parallel analysis. Science 285, 901-906.

Yoshida, K., Shindo, K., Sano, H., Seki, S., Fujimura, M., Yanai, N., Miwa, Y. \& Fujita, Y. (1996). Sequencing of a $65 \mathrm{~kb}$ region of the Bacillus subtilis genome containing the lic and cel loci, and creation of a $177 \mathrm{~kb}$ contig covering the gnt-sacXY region. Microbiology 142, 3113-3123.

Yoshida, K., Aoyama, D., Ishio, I., Shibayama, T. \& Fujita, Y. (1997). Organization and transcription of the myo-inositol operon, iol, of Bacillus subtilis. J Bacteriol 179, 4591-4598.

Received 13 September 1999; revised 18 October 1999; accepted 18 November 1999. 